\title{
SMEs and social responsibility a holistic approach
}

\section{Las PyMes y la responsabilidad social un enfoque holístico}

\author{
BIVIANO-PÉREZ, Emma*†, SOSA-LARRAINZAR, Evelyn and GARCÍA-SÁNCHEZ, Avelina
}

Universidad Tecnológica de Puebla

ID $1^{\text {st }}$ Author: Emma, Biviano-Pérez / ORC ID: 0000-0002-3467-3620, Researcher ID Thomson: Q-9727-2018, CVU CONACYT ID: 370523

ID $1^{\text {st }}$ Coauthor: Evelyn, Sosa-Larrainzar / ORC ID: 0000-0002-4799-9363, Researcher ID Thomson: Q-9787-2018, CVU CONACYT ID: 266218

ID $2^{\text {nd }}$ Coauthor: Avelina, García-Sánchez

DOI: $10.35429 /$ JMPC.2019.16.5.21.26

Recibido June 26, 2019; Aceptado December 28, 2019

\begin{abstract}
The issue of Social Responsibility in companies has a lot of its characteristics, even though it is a subject that belongs to every entity, it cannot be promoted in the same way nor do the results have the same impact. Discovering the correct form implies its observation from a holistic point of view since it goes far beyond just taking care of the external environment but also the internal one. Each of the elements that comprise it is part of that economic unit and therefore it is not correct to divide the whole. In this case, the Human Element is considered in the first instance, secondly, the Financial Resources and thirdly the Base Systems or processes with which small and mediumsized enterprises (SMEs) operate. The purpose of this study is to demonstrate the importance of considering all the elements of an organization to promote corporate social responsibility, identify the actions carried out through daily interaction in the life of the entity and also the existing interdependence to achieve positive effects. . Likewise, the microentrepreneur's perspective is shown before the great challenge of adopting this culture. In the first part, the general characteristics of the SMEs are identified, then the results corresponding to a phase of a qualitative, descriptive investigation, carried out on a random sample of organizations located in the Northeast Zone of the city of Puebla, are presented through the collection of data in situ.
\end{abstract}

Interaction, Business elements, CSR

\begin{abstract}
Resumen
El tema de la Responsabilidad Social en las empresas versa mucho de sus características, aún cuando es un tema que compete a toda entidad no se puede promover de la misma forma ni los resultados tienen el mismo impacto. El descubrir cual es la forma correcta implica su observación desde un punto de vista holístico ya que va mucho más allá de solo cuidar el medio ambiente externo sino también el interno. Cada uno de los elementos que lo integran forma parte de esa unidad económica y por ende no es correcto fraccionar el todo. En este caso se considera el Elemento humano en primera instancia, en segundo lugar, los Recursos financieros y en tercer lugar los Sistemas o procesos base con que operan las pequeñas y medianas empresas (PyMes). El presente estudio tiene como fin evidenciar la importancia de considerar todos los elementos de una organización para promover la responsabilidad social empresarial, identificar las acciones que se realizan mediante la interacción diaria en la vida de la entidad y así mismo la interdependencia existente para lograr efectos positivos. Así mismo se muestra la perspectiva del microempresario ante el gran reto que implica adoptar esta cultura. En la primera parte se identifican las características generales de las PyMes, posteriormente se presentan los resultados correspondientes a una fase de una investigación cualitativa, descriptiva, realizada a una muestra aleatoria de organizaciones ubicada en la Zona Noreste de la ciudad de Puebla, mediante la recolección de datos in situ.
\end{abstract}

Interacción, Elementos empresariales, RSE

Citation: BIVIANO-PÉREZ, Emma, SOSA-LARRAINZAR, Evelyn and GARCÍA-SÁNCHEZ, Avelina. SMEs and social responsibility a holistic approach. Journal of Microfinance Planning and Control. 2019, 5-16: 21-26

\footnotetext{
* Correspondence to Author (email: emma.biviano@utpuebla.edu.mx)

$\dagger$ Researcher contributing first author.
} 


\section{Introduction}

The current global competitiveness requires an enormous commitment for all business organizations, on the one hand, consumers require a greater diversity of products, innovative and at a good price, on the other hand, they find a number of similar or substitute products and at the same time inputs, labor, transportation and operation costs make up a scenario that is very difficult for small and medium-sized companies to overcome. These aspects are recognized by any Mexican or foreign businessman, small or large, since they are factors that characterize the business world.

If we join to these points the increasingly bureaucratic public policies, social problems and corporate social responsibility that concerns any organization given that it is part of the natural ecosystem and of a social scheme that concerns all human beings, the business scenario expands its horizons and becomes a survival challenge. When starting with the study of Corporate Social Responsibility aligned to Small and Mediumsized enterprises, it is important to know its characteristics in detail.

Cajiga (2018) states that Corporate Social Responsibility (CSR), is a concept that implies that the company ensures that its operations are sustainable in the economic, social and environmental aspects, recognizing the interests of the different groups with which it relates to and seeks the preservation of the environment and the sustainability of future generations.

In the Corporate Social Responsibility (CSR) strategy, there seems to be an implicit assumption that "what is good for the company is good for society" (Romero 2010, cited by Montoya, 2012). This is a circumstantial approach that is opposed to a reality that has generated many negative effects on the environment and therefore on the social ecosystem.

Montoya's (2012) proposal to conceive the company in a holistic and systemic way as part of an interrelated whole to which attention and resources must be dedicated to improve its position in the market is a proposal to consider in today's companies and of tomorrow.
Based on Cajiga's (2015) statement that there are four strategic areas that allow the presence of Corporate Social Responsibility to be identified in the operational life of organizations; Ethics and corporate governance, Quality of life in the company, Bonding and commitment to the community and its development, Care and preservation of the environment, it is essential to develop these aspects within the organization considering all the roles involved in the company.

Another interesting approach mentions that: "Social responsibility favors any initiative that originates in the company, facilitating the positioning of its brand, renewing its corporate image, capturing the preference and loyalty of its customers ..." (Rodríguez, 2016).

From this perspective for any organization regardless of size, adopting the role of a socially responsible company is convenient for its development and growth, therefore it is essential to lay the foundations to achieve it and Human Capital due to its importance in any organization is one of the interest groups in which companies should rely to promote their professional development (López, 2016).

Now in analyzing why it is important for an organization to be socially responsible; the DESUR guide, (Developed Sustainable Regions Through responsible SMEs) (2015) mentions internal and external benefits, within the internal considers;

Improve the confidence of potential investors, attract and retain talented people, Position and differentiate the brand, Capture new customers, retain customers, Improve corporate image, Improve relationship with the environment. (p.7).

Regarding external benefits, it includes motivating employees, improving the work environment, resulting in improved productivity and quality in service provision, improving internal communication, obtaining loyalty and commitment from staff, creating culture in the organization, through the promotion of shared values in the company (p.7). 
Under the premise that organizations are part of a globalized world in which their success does not depend on their profits alone, but it is required to contribute with all those who participate in it to make them more competitive (Rodríguez, 2016). This is a comprehensive approach that involves the involvement of all the elements that make it up.

Considering that those who intervene within organizations are Financial Resources, Human Capital and Systems or processes, it is necessary to specify the characteristics and conditions that each entails.

Pierina (2012) expresses that the survival of small companies is limited by the deficiency of three resources; financing, labor and skilled leadership and technology

Regarding financing, it is indisputable that it has a direct relationship with growth and since it is scarce in MSMEs, its chances of success are few.

On the other hand, the small companies that are mostly family-based, have unskilled personnel to carry out the functions proper to their operation, and this aspect detracts from the productivity of the organization (Pierina, 2012).

The Mexican Center for Philanthropy, CEMEFI, (2016), marks four areas of Corporate Social Responsibility, Quality of life in the company, Business Ethics, Linking the company in the community and care and preservation of the environment.

If these points are aligned to the elements that make up the company, Quality of life directly involves human Capital within its work environment, which entails the generation of jobs with fair and timely wages Barroso (2008), in addition to promoting the Staff development considering continuous training relevant to the position held, improving communication skills, among others.

To comply with the aspects of Business Ethics, Linking the company in the community, every organization requires taking care of the environment that surrounds them, promoting values and promoting these same aspects also with the external agents that are related, under the premise of win-win (Barroso, 2008).
Being aware of the economic capacity of companies, only some organizations (medium and large) will have the possibility of complying with these aspects and the question remains: What to do in small organizations? These represent a great challenge that involves the involvement of the industry, the government and the institutions that are also known as the triple helix model (Ponce, 2017).

\section{Methodology}

In order to know the elements that must be considered in a MyPyMe to implement the Culture of Corporate Social Responsibility with a holistic approach, a research was developed with a qualitative approach, with information obtained through the application of surveys to 200 micro and small organizations located in the Northeast area of the city of Puebla, selected by means of a random sampling for convenience, with an exploratory, descriptive nature, using an instrument that served as the basis for gathering information in situ, under the hypothesis that states: the term corporate social responsibility does not it only covers aspects of caring for the environment, since the social aspect involves the quality of life of human beings and the work environment in which they carry out their activities.

\section{Results}

This section shows some of the results obtained in the on-site information gathering stage, with the intention of showing the reality that prevails in companies with respect to Ethics and corporate governance, Quality of life in the company, Bonding and commitment with the community and its development, Care and preservation of the environment

The results obtained in the research carried out show that the vast majority have from 1 to 5 employees, (see graph 1) and a minority has a range of 6 to 10 employees, therefore they correspond to the category of micro-enterprises (DOF, 2019). 


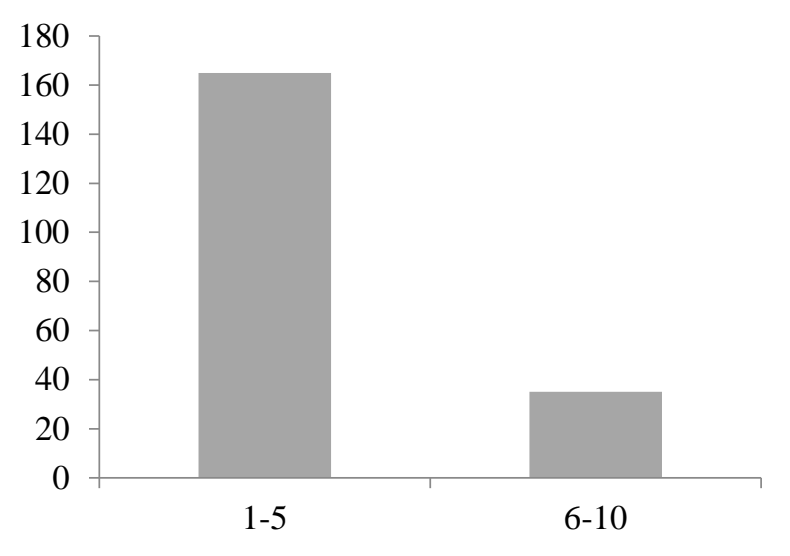

Graphic 1 Number of employees hired Source: Self Made (2019)

The ages of the respondents range from 20 to 65 years, observing in the results that the vast majority are young entrepreneurs, this aspect is important since it allows new trends to be implemented because they are open-minded generations and well in the globalization ecosystem, see Graphic 2.

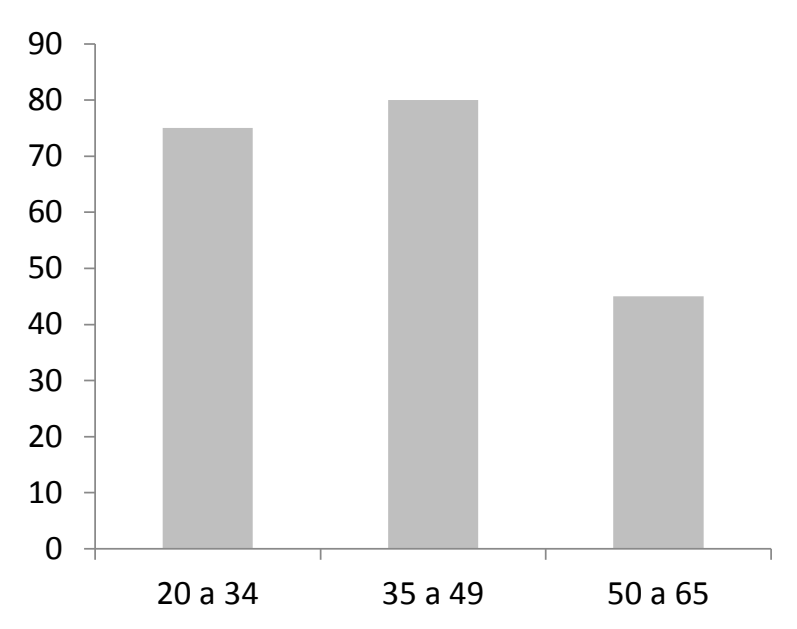

Graphic 2 Age of businessmen surveyed Source: Self Made (2019)

\section{Ethics and corporate governance}

One of the essential aspects to achieve a healthy work environment is to have good communication, analyzing the results of the applied survey show that the employees who are working consider that they have good communication between themselves and the employer and only in $18 \%$ they consider there is poor communication see Graphic 3.

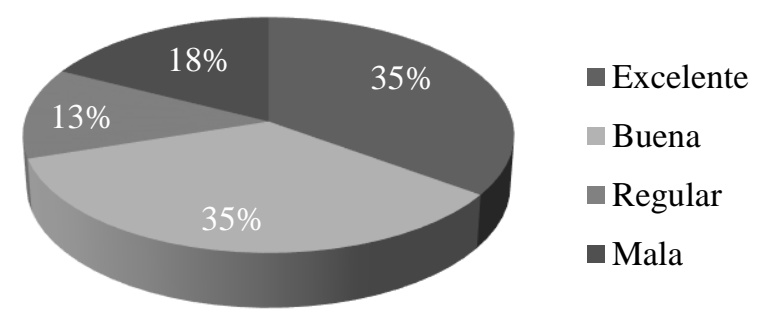

Graphic 3 Communication between boss-employee Source: Self Made (2019)

In order to achieve a favorable working climate, it is necessary to generate a good level of coexistence within the organization, in the majority of microenterprises there is no problem as observed in Graphic 4, the achievement of this objective is hindered when the workforce is dense since it is much more difficult to control personnel.

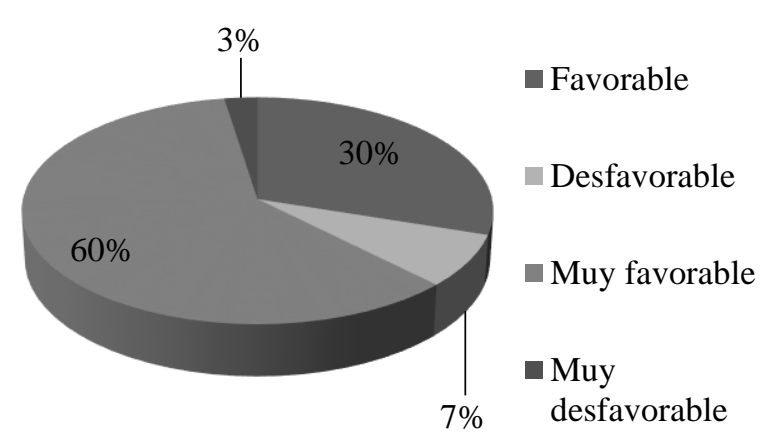

Graphic 4 Comunicación entre jefe- empleado Source: Self Made (2019)

In the study carried out, it is observed that in $90 \%$ of companies the coexistence between employees is favorable and only $10 \%$ of employers indicate that the relationships between their staff are not favorable.

Quality of life

Among the aspects indicated by the ISO 26000 Standard regarding the quality of life that must exist among its employees, it mentions that safety and health must be considered at work, these points are essential for the worker to have certain stability and safety in the work and this is achieved by decreasing the hiring of eventual personnel and opting for indefinite contracts. 
To verify the behavior of employability in the surveyed organizations, employers were asked how the number of employees on their payroll has varied, it is observed that most of them are permanent employees and some have even been hired. This aspect indicates that the organizations are in development, being the ideal time to implement new policies, including its foray into the field of Social Responsibility see Graphic 5.

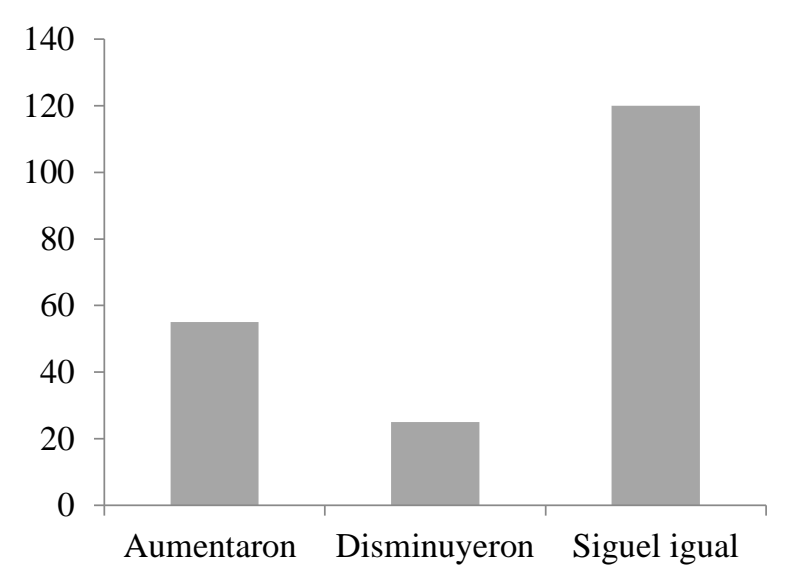

Graphic 5 Employability level behavior Source: Self Made (2019)

Aspects of equality in people:

It is considered that a healthy work environment contributes to a good level of productivity in organizations and, in addition to this, it is essential to promote equality between collaborators and companies must hire personnel based on their knowledge, skills and abilities, not by have characteristics that are not related to their job performance (Wheelen \& Hunger, 2007) mentioned by Mendoza, Ávila, Meza, Zambrano and Chavarría (2018, p. 210).

For this aspect, it begins in the selection of personnel to work in the companies and to inquire at the point, the interviewees were asked if they would hire someone who had an impediment to listening, speaking, walking or seeing and the answer reflects an advance in the However, acceptance of this policy is not enough to consider that it has permeated the culture of social responsibility, since $57 \%$ agree to provide an opportunity to disabled people, however, $43 \%$ disagree or are in an uncertainty, see Graphic 6.

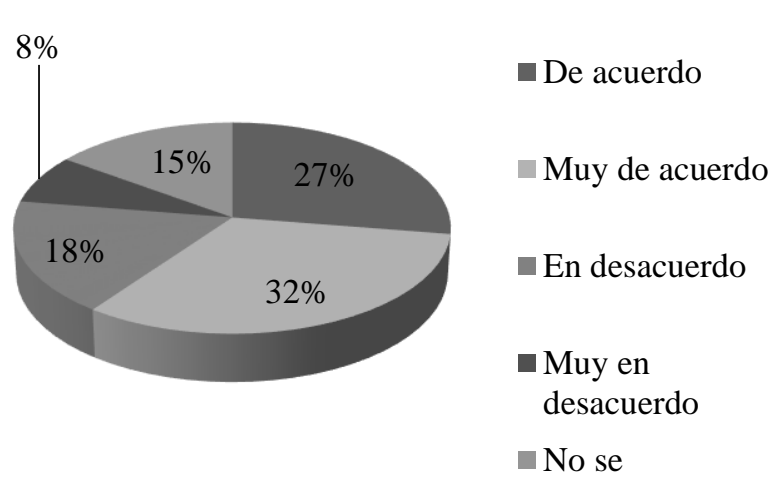

Graphic 6 Hiring of people with disabilities Source: Self Made (2019)

Entrepreneurs were also asked if they would hire someone who has HIV, only $40 \%$ of employers expressed their agreement to hire people with the aforementioned disease and the remaining $60 \%$ stated that they did not agree with it due to lack of information. of the condition see Graphic 7.

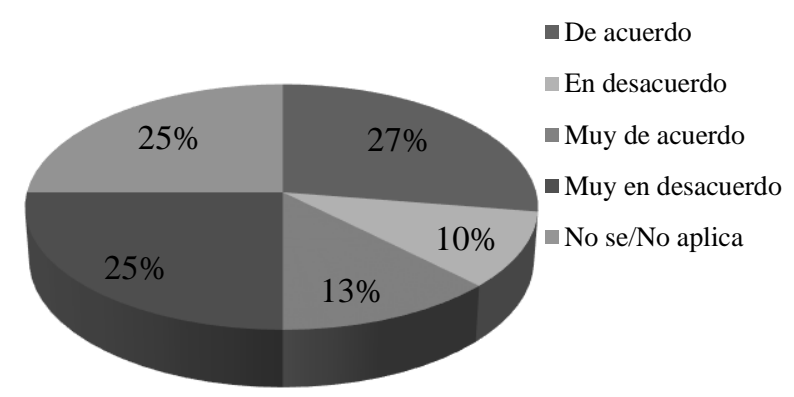

Graphic 7 Hiring people with a history of HIV Source: Self Made (2019)

\section{Conclusions}

Once the results obtained in the study carried out on the sample of organizations located in the Northeast Zone of the city of Puebla have been interpreted, it is concluded that very few are the actions carried out to achieve an organizational culture with corporate social responsibility, even when it is the current trend it has not permeated enough.

The implementation of organizational policies must consider aspects of corporate governance, quality of life for the human capital that works in them and measures for caring for the environment. 
To start with its implementation, it is essential to formalize the status of organizations in the legal field, and aware of the regulations they must comply with and according to the prevailing line of business or activity.

It is essential to start with a change gradually as what is intended is a general new culture within the company. The size of the organizations will undoubtedly be a point in favor or against to achieve effective results, however, if it is possible to implement it in any organization and it will obviously generate positive changes for all the members of the entity and its environment.

\section{References}

Barroso, T. F. (2008). La responsabilidad social empresarial. Un estudio en cuarenta empresas de la ciudad de Mérida, Yucatán. (Scielo, Ed.) Contaduría y Administración (226).

Cajiga, C. J. (2015). CEMEFI. Argentina: Trillas.

Cajiga, Calderón Juan Felipe. (01 de 08 de 2018). El concepto de Responsabilidad Social Empresarial. Obtenido de CEMEFI: https://www.cemefi.org/esr/images/stories/pdf/e sr/concepto_esr.pdf

CEMEFI, Centro Mexicano para la filantropía A.C. (2016). Guía de participación para el proceso de obtención del Distintivo ESR . Guía de participación para el proceso de obtención del Distintivo ESR .

DESUR, (Developed Sustainable Regions Through responsible SMEs. (09 de 2015). DESUR. Obtenido de http://responsabilidadsocialquito.com.ec/wpcontent/uploads/2015/09/DESUR-guia-final.pdf

DOF, D. O. (28 de 02 de 2019). INADEM. Recuperado el 11 de 08 de 2019, de https://www.inadem.gob.mx/wpcontent/uploads/2019/02/ROFNE2019_280220 19.pdf
López, S. A. (2016). La responsabilidad social empresarial desde la percepción del capitalhumano. Revista de Contabilidad (20), 36-46. Recuperado el 10 de 08 de 2019, de https://reader.elsevier.com/reader/sd/pii/S11384 8911600011X?token $=435249$ CB2EF71BC890 C4DFF3E6FB9275A845079222181D4B654D3 8D456EE2EA2BDAD55442C0B1DA8AD0ED 029D0238201

Mendoza, V. A. (2018). La responsabilidad social y las Pymes en el Ecuador. III Congreso Virtual Internacional sobre Desafíos de las Epresas del Siglo XXI, 207-230.

Montoya, A. B. (2012). Responsabilidad Social Empresarial: Una respuesta ética ante los desafíos globales. México: Rood.

Pierina, D. R. (2012). Administración de Pequeñas Empresas. Estado de México: Red Tercer Milenio.

Ponce, J. I. (2017). Asociación Latino Iberoamericano de Gestión Tecnológica. (ALTEC, Ed.) Recuperado el 10 de 08 de 2019, de http://www.uam.mx/altec2017/espanol/ponenci as.html

Rodríguez, M. A. (2016). Responsabilidad Social Empresarial como factor de Sustentabilidad para el mejoramiento del capital Humano en las Empresas Mexicanas. Contaduría y Administración. Recuperado el 10 de 08 de 2019, de http://congreso.investiga.fca.unam.mx/docs/xxi/ docs/11.05.pdf 